\title{
Researching non-formal religious education: The example of the European study on confirmation work
}

\begin{tabular}{|c|c|}
\hline \multicolumn{2}{|c|}{$\begin{array}{l}\text { Author: } \\
\text { Friedrich Schweitzer }{ }^{1,2}\end{array}$} \\
\hline \multicolumn{2}{|c|}{$\begin{array}{l}\text { Affiliations: } \\
\text { 'Department of Practical } \\
\text { Theology/Religious Education, } \\
\text { Faculty of Protestant } \\
\text { Theology, University of } \\
\text { Tübingen, Germany }\end{array}$} \\
\hline \multicolumn{2}{|c|}{$\begin{array}{l}{ }^{2} \text { Department of Practical } \\
\text { Theology, Faculty of } \\
\text { Theology, University of } \\
\text { Pretoria, South Africa }\end{array}$} \\
\hline \multicolumn{2}{|c|}{$\begin{array}{l}\text { Research Project Registration: } \\
\text { Project Leader: Y. Dreyer (1) } \\
\text { Project Number: } 2546930\end{array}$} \\
\hline \multicolumn{2}{|c|}{$\begin{array}{l}\text { Description: } \\
\text { Prof. Dr Schweitzer is } \\
\text { participating in the research } \\
\text { project, 'Gender Studies and } \\
\text { Practical Theology Theory } \\
\text { Formation', directed by Prof. } \\
\text { Dr Yolanda Dreyer, } \\
\text { Department of Practical } \\
\text { Theology, Faculty of Theology, } \\
\text { University of Pretoria. }\end{array}$} \\
\hline \multicolumn{2}{|c|}{$\begin{array}{l}\text { Corresponding author: } \\
\text { Friedrich Schweitzer, } \\
\text { friedrich.schweitzer@ } \\
\text { uni-tuebingen.de }\end{array}$} \\
\hline \multicolumn{2}{|c|}{$\begin{array}{l}\text { Received: } 28 \text { Apr. } 2017 \\
\text { Accepted: } 10 \text { June } 2017 \\
\text { Published: } 26 \text { July } 2017\end{array}$} \\
\hline \multicolumn{2}{|c|}{$\begin{array}{l}\text { How to cite this article: } \\
\text { Schweitzer, F., 2017, } \\
\text { 'Researching non-formal } \\
\text { religious education: The } \\
\text { example of the European } \\
\text { study on confirmation work', } \\
\text { HTS Teologiese Studies/ } \\
\text { Theological Studies } 73(4) \text {, } \\
\text { a4613. https://doi.org/ } \\
\text { 10.4102/hts.v73i4.4613 }\end{array}$} \\
\hline \multicolumn{2}{|c|}{$\begin{array}{l}\text { Copyright: } \\
\text { (c) 2017. The Authors. } \\
\text { Licensee: AOSIS. This work } \\
\text { is licensed under the } \\
\text { Creative Commons } \\
\text { Attribution License. }\end{array}$} \\
\hline \multicolumn{2}{|l|}{ Read online: } \\
\hline 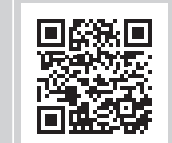 & $\begin{array}{l}\text { Scan this QR } \\
\text { code with your } \\
\text { smart phone or } \\
\text { mobile device } \\
\text { to read online. }\end{array}$ \\
\hline
\end{tabular}

\section{Author:}

\section{Affiliations:}

Department of Practical

Faculty of Protestant

Theology, University of

Tubingen, Germany

Theology, University of

Pretoria, South Africa

Registration: Project Leader: Y. Dreyer

Description:

Prof. Dr Schweitzer is project, 'Gender Studies and Practical Theology Theory Formation', directed by Prof. Dr Yolanda Dreye Theology, Faculty of Theology,

Corresponding author: Friedrich Schweitzer, friedrich.schweitzer@

\section{Dates:}

Accepted: 10 June 2017 religious education: The example of the European study on confirmation work', HTS Teologiese Studies/ a4613. https://doi.org/

\section{Copyright:} Licensee: AOSIS. This work

is licensed under the

Creative Commons

Attribution License.

Read online:
This article discusses the need for researching non-formal religious education as a neglected field of empirical research in religious education. By describing the growing awareness of the theological and educational meaning and importance of non-formal education and by reviewing the literature on research in religious education which appears to be focused somewhat one-sidedly on the formal context of the school and of the school subject of Religious Education, the author creates a background for the presentation of current research on confirmation work in Europe. The author gives an overview on a more than 10-year-long project on confirmation work in nine European countries, with an emphasis on the research design, methods, and main results. The experiences from this project are then discussed from the perspective of research on non-formal religious education. Finally, the author considers implications of this research for religious education and practical theology in general.

\section{Introduction}

For more than 10 years, one of my main research tasks has been directed at confirmation work in Europe. The study includes Germany where I myself live and work, as well as eight other countries or churches that are part of the study (Austria, Denmark, Finland, Hungary, Norway, Poland, Sweden and Switzerland). At this point, most parts of the study have been completed. The results are accessible in a number of books in several languages (in English cf. Schweitzer, Ilg \& Simojoki 2010; Schweitzer et al. 2015; 2017) and there is no need to repeat what can be found in these volumes. However, the study has a number of general implications for research in religious education and in practical theology which have not yet been described and discussed in any detailed manner. In others words, I want to use the present article as an opportunity for discussing some of these implications more thoroughly and to advance our understanding of the needs and possibilities of research in religious education and practical theology.

For this purpose, I suggest to consider confirmation work as an example of what has come to be called non-formal education. While the understanding of this concept will be laid out in more detail in the following, it should be clear from the beginning that it refers to non-compulsory nonschool-type settings which, however, still imply some kind of institution or institutional framework as their basis. This institutional reference is what distinguishes non-formal from informal settings or situations, which explains why this concept may be especially suitable in the context of Christian congregations.

Confirmation work is also a comparatively new concept which refers to what in earlier times, in the Protestant tradition until the 1960s and 1970s, was called confirmation instruction or preparation for confirmation. In many Protestant churches, confirmation is celebrated around the age of 14 years, after a period of so-called confirmation time of one or two years. Following the terminology of earlier times, preparation for confirmation can also be called catechesis, which was often based on rote learning. In contrast to traditional forms of catechesis, the modern concept of confirmation work now in use refers to ways of working with young people, which are closer to general youth work than to traditional school teaching.

For Protestants it has always been clear that confirmation work has to do with getting to know and to understand - the Christian faith. That the respective programmes can be viewed as nonformal education, however, is a new development which deserves special consideration. At the same time, as will be shown in the following, it is this understanding which makes confirmation work an interesting topic for research.

Finally, it is probably fair to say that research concerning questions of education in practical theology and religious education (which sometimes is considered a sub-discipline of practical 
theology and sometimes a discipline of its own) has mainly been directed at the school subject Religious Education. Other fields like confirmation work but also Christian children and youth work, Sunday School, adult education, etc., have received much less attention. Given the increasing awareness of the influence and importance of learning processes beyond the school in the perspective of general education, this traditional research focus appears questionable and in need of being broadened. Similarly, the lack of research concerning religious educational fields beyond Religious Education at school is to be deplored theologically because it means that a whole area of churchrelated work goes mostly unnoticed in the academic discussion. Moreover, its importance is also likely to escape the awareness in church leadership as long as no respective research results are presented.

\section{Non-formal religious education: $A$ major field of Christian education and church work}

The Protestant tradition in education has its roots in Reformation time (cf. Schweitzer 2016). Martin Luther as well as many others of the 16th-century Reformers demanded that Scripture should become a major topic in all schools from early on (cf. Luther 1982a:230). This was the beginning of the systematic introduction of Religious Education as a school subject which, until today, plays a major role in many countries around the world, although not related to the church or to Christianity in all cases but based on some kind of secular or religiously neutral religious studies. In today's educational terminology (cf. Bundesministerium für Bildung und Forschung 2008), schools are the main type of formal education. They have a highly formalised institutional basis and attendance is mandatory for all children and youth. The 16th-century Reformers emphasised the role of schools for Christian instruction because they wanted schools to not fall short of the faith-related topics considered crucial by them for all education. Moreover, they saw little hope in encouraging or admonishing parents to take over the tasks of religious education. They thought that many parents would not be willing or able to do so (cf. Luther 1982b). The contemporary (religious) educational discussion is very much aware of the strong influence of informal education - in the family or with the media or other sources important to young people in their free time, like being with their peers, etc. Yet possibilities for influencing the largely private world of non-institutionalised and uncontrolled informal processes are very limited. Neither state nor church are in a position to exert much influence in this direction. Beyond encouragement and admonishment, there may be programmes, for example, supporting parents in their tasks of nurturing their children. But it is often unclear how effective such programmes will really be. Concerning informal religious education, there is basically no empirical evidence for the effectiveness of respective programmes offered for parents, for example, by congregations.
It is at this point that non-formal education becomes interesting. This third type of education includes programmes that have a certain institutional basis, although much less so than schools; most of all, participation in non-formal educational programmes is not mandatory, which often makes them especially attractive for young people who prefer to make their own decisions about participation rather than being obliged to attend. At the same time, as opposed to informal education, such programmes can be influenced and shaped intentionally, among others, by their sponsors' aims but also by educational or theological views and theories, at least to some degree. As far as the disciplines of religious education and practical theology have taken interest in the non-formal sector, they have also been able to exert at least some influence on it. This can also be seen from the example of confirmation work, which has repeatedly been the object of practical theological theories and conceptualisations (cf. Bäumler \& Luther 1982). The transition from traditional confirmation instruction to confirmation work mentioned above can be seen, at least in part, in connection to such theoretical and theological developments.

Again since the Reformation, Protestantism emphasised the need for Christian instruction not only in school or in the family, but also in the congregation. Special worship services with catechetical sermons were introduced, at different times on Sundays but also during the week (cf., for example, Jetter 1988). Many of the Protestant churches in Germany introduced classes preparing young people for confirmation in the 16th century, and in the course of the 18th century, such classes became a standard part of Protestant education in many Churches (cf., for example, the brief historical account by Vischer 1958). In most cases, the Protestant catechisms Luther's Small Catechism or the Heidelberg Catechism for the Reformed, as well as many other catechisms - played a key role in confirmation instruction. If it is legitimate to make use of today's categories for earlier times, this was the beginning of non-formal religious education within Protestantism and, at least in many ways, it also became the model for comparable programmes used by the Catholic Church, even if the contents were different (cf. Paul 1995).

Concerning the Protestant tradition to which I will limit myself here, a whole number of educational programmes emerged during the centuries since the Reformation (for a condensed overview, cf. Schweitzer 2016). Many of them can be counted as varieties of non-formal religious education as well. This applies especially to the Sunday School with its beginnings in the 18th and 19th century, groups for children and youth which started in the 19th century, and forms of adult education sponsored by the church especially since the turn of the 20th century (the chronological description applies to Germany where many of the respective programmes started, and will naturally be different in other countries). In addition to this, less defined programmes developed in the context, for example, of diaconal social work or as part of social movements, for example, in the context of ecological education or education for peace. Again, the forms of learning and education connected to them can be considered varieties of non-formal education. 
In addition to the general interest in education characteristic of the Protestant tradition, there are additional theological reasons for appreciating the non-formal sector. This applies, for example, to the Protestant understanding of the church or ecclesiology. Non-formal forms of education are often characterised by strong participation of volunteers, which can be viewed as an expression of the Protestant teaching of the priesthood of all believers. This may also explain the special affinity between Protestantism and non-formal education.

In sum then it can be argued that the Protestant educational tradition and heritage clearly encompasses informal, formal and non-formal religious education. Consequently, no account of this tradition can be complete which does not make reference to all three types of religious education - a claim that I want to pursue here with special emphasis on non-formal programmes.

\section{Non-formal religious education as topic of research}

In my understanding, research in religious education comprises different approaches (cf. Schweitzer 2006). Today, the most common approaches on this field are historical accounts, systematic analysis and empirical studies. In addition, international comparative approaches and evaluative studies have also gained an interest. All these approaches remain important for the future. For the present article, however, I will limit myself to empirical research which, at the same time, can also be internationally comparative and can include aspects of evaluation as well.

Concerning empirical research in religious education, several attempts have been made to map the terrain and offer respective overviews on existing studies, for example, in handbooks (Hyde 1990; Strommen 1971) or in volumes documenting summary discussions (Francis, Kay \& Campbell 1996; Jackson 2012; Larsson \& Gustavsson 2004; Schreiner \& Schweitzer 2014; Schweitzer \& Boschki 2017). According to such overviews, the largest part of research in the field of religious education is about children and youth, especially concerning their religious attitudes, development, orientations and interests. Studies looking into this direction are naturally of interest to all fields of religious education working with children and youth, including non-formal religious education. Yet their aim most often is not to elucidate the religion they are studying in relationship to particular teaching or learning programmes or educational institutions, structures or contexts. In this sense, this body of research clearly is not about nonformal religious education.

Studies with a focus on teaching and learning or on institutional settings most often refer to Religious Education as a school subject. It seems to be an almost natural assumption that research in this field should be about this subject - an orientation of research which reflects the United Kingdom use of the term 'religious education' only in reference to the school while calling educational processes in family and congregation 'religious nurture' (cf. Hull 1984). This terminological decision seems to imply, although not necessarily by its intentions, that what happens in informal or non-formal religious education is less educational or even less important which, as another consequence, may be understood to mean that it also does not deserve to be researched. This understanding would, however, be mistaken because there can hardly be any doubt that informal and nonformal religious education can be highly influential - in terms of society and in relationship to the church but also, via the attitudes acquired by the children and adolescents in informal or non-formal contexts, which make themselves felt at school as well, no less in terms of Religious Education at school. Even if non-formal religious education is not accepted as educational - a view that must be contested - it should therefore be studied empirically.

Another field that has received special attention in empirical research concerning religious education at least in some countries are church-sponsored schools. The publications quoted above include a number of empirical studies concerning such schools especially from the United Kingdom. This interest seems to reflect the important role that schools sponsored most of all by the Church of England still play in the United Kingdom (as well as in some other countries), although there also is some research on churchsponsored schools, for example, from Germany where the number of such schools is rather small. Again, this research is important, especially for the further development of these schools. Yet even where church-sponsored schools open up choices for parents and pupils who may prefer non-state schools, the church-sponsored schools remain part of the mandatory system of formal education. Their basis is the obligation for children and youth to attend school, often including Religious Education.

In sum then, it seems fair to state that non-formal religious education has not been a main concern of empirical research in religious education so far. There are examples of such studies but most often these studies were rather limited in scope (for earlier studies on confirmation work, see the overview in Schweitzer \& Elsenbast 2009). This implies that little is known about the actual quality and impact of forms of religious education beyond the school which, in turn, also proves that there is no empirical basis for claiming that these forms are not important, have no educational effects or are lacking in educational quality. Instead, religious education as a research discipline appears to have followed the main modern drift of identifying education with schools and to have mistaken the terminological distinction between 'education' and 'nurture' as a valid reason for not doing research beyond the school.

Another reason for the lack of research on non-formal religious education may have to do with the issue of feasibility. For obvious pragmatic reasons, institutions like schools offer comparatively good presuppositions for research. Schools are clearly defined institutions and often there are official lists of the schools in a given region, state or 
country that can be used for purposes of research. Because school attendance is highly regulated and the pupils are clearly organised in groups or classes, access, for example, to interviewees can more easily be secured than in the absence of such presuppositions, etc. Comparable presuppositions do not exist in the non-formal sector, which therefore may be more difficult to study. Yet again, such considerations can hardly justify not doing research in the non-formal sector. They refer to practical challenges but they do not imply that the effects of non-formal religious education are not important and do not deserve attention in research.

Against the background of lack of research on non-formal religious education, I want to describe the current research on confirmation work in Europe not just as a research project but as an example of researching non-formal religious education in general.

\section{Researching confirmation work in Europe: Design, procedures and selected results}

As pointed out above, confirmation work in Europe can be considered a prime example of non-formal religious education. In European countries with a sizable Protestant population like Germany, about one third of the general population at the age of 14 takes part in this programme (cf. Schweitzer et al. 2010). This means that, in Germany, for example, between 200000 and 250000 adolescents participate per year, depending on the demographically variable size of the respective age group. This implies that confirmation work is not only important for the Protestant Churches offering this programme but also for society at large. Taking the nine countries mentioned above participating in the international study on confirmation work together, the number of confirmands is about half a million per year.

Confirmation time in Europe typically lasts between one and two years, depending on the country or region (cf. the country reports in Schweitzer et al. 2010; 2015). It typically includes some formal teaching but also many other activities like playing games, doing creative projects, internships, camps, outings, etc. While it originally relied on traditional school teaching as its guiding model, among others with the now infamous rote learning of the catechism and with set school-hours once or twice per week, it now is organised in a rather flexible manner. Weekends are used for finding more time with the adolescents and longer outings and camps have come to play a key role. Moreover, most often it is not only the minister alone who is in charge of this programme anymore. Instead, he or she shares the work with a number of volunteers who, in many cases, are not much older than the confirmands themselves.

In spite of the quantitative extension of confirmation work, it had not been the object of major empirical studies until recently. With the exception of Finland where such research started earlier than in other countries (cf. Niemelä 2008), only minor and often non-representative studies were available (cf. the overviews in Schweitzer \& Elsenbast 2009). This observation, together with the realisation that the actual importance of this field of work was widely not adequately appreciated in church or society and that empirical research could also help to improve the practice of confirmation work, became the starting point for a 10-year-long empirical research project carried out first in seven and later in nine European countries, in the meantime also with a parallel project in the United States (cf. Douglass 2015).

In the following I will first offer a brief description of the project's design and procedures and then summarise some of its main results.

\section{Research design and procedures}

The project actually comprised two studies, the first one with data collection in 2007 and 2008, the second one with data collected from 2012, 2013 and 2015. The second study repeated major parts of the first study in order to allow for comparisons over time. Moreover, both studies were longitudinal in that the same adolescents had to fill in questionnaires at the beginning and at the end of their confirmation time. In addition, with the second study, another questionnaire was sent out two years after confirmation in order to gain first insights into possible longterm effects of confirmation work.

The first aim of the whole study was to achieve a multiperspective empirical description of confirmation work, including as many aspects of the practice of this programme as possible. The study therefore included the views of the adolescents taking part in this programme as well as that of the workers, both ministers and other full-time employees in charge of the programme as well as volunteers. In some of the countries, questionnaires were also completed by parents of the confirmands. Although the study also included some qualitative parts, the main emphasis was quantitative because it aimed for representative results. Research questions referred to expectations and experiences concerning confirmation work but also to religious upbringing and religious attitudes. The second study added a special emphasis on young people becoming volunteers after confirmation and on the adolescents' relationship to the church.

The study was carried out in nine European countries (see above). The participating Churches were either Lutheran or Reformed. In the second study, the Methodist Church in Germany also took part. The aim was to have samples that would be as representative for the participating countries as possible. This was considered important in terms of gaining valid results as well as for securing a sound basis for international comparison. With more than 28000 confirmands taking part, for example, in the 2012 and 2013 study this aim was clearly achieved. Concerning the part of the study two years after confirmation, however, it was not possible to work with representative samples because there is no 
institutional basis for reaching young people after the end of confirmation time. The data from this part of the study are of interest in terms of their longitudinal character, making it possible to trace developments on an individual level over several years.

\section{Main results}

The results from the international studies have been published in English in three volumes (Schweitzer et al. 2010; 2015; 2017), in addition to other publications in the national languages of the participating countries. The results shed light on many aspects of the practice of confirmation work, including possible improvements, adolescents' faith and religious attitudes, their relationship to the church, experiences with becoming and being a volunteer in confirmation work, etc. Some of the main results can be summarised as follows:

- Approval rates: Across the participating countries, confirmation work receives very high approval from all groups involved in the programme, from the adolescents as well as the ministers and other workers or the volunteers. The average for the participating countries is $76 \%$ approval from the confirmands - a result that should be counted as a real success, even if those less satisfied with the programme should not be overlooked.

- Religious attitudes: The religious attitudes show a mixed picture, which must be interpreted against the background of the high participation rates and the fact that it is not only adolescents especially interested in faith or religion who take part in confirmation work. At the beginning of confirmation time, only very general religious statements like 'I believe in God', 'God loves all humans and cares about each one of us' or 'There is life after death' find approval from a clear majority of the confirmands. More clearly, Christian views like 'Jesus has risen from the dead' receive much less approval (Schweitzer et al. 2015:366):

- Many of the religious attitudes addressed by the study are strengthened during confirmation time, thus following the expectations of the church. Yet 2 years after confirmation, most of these positive effects had disappeared, although the 16 year olds also showed some increased religious interests in certain respects, most of all concerning life after death.

- One of the most challenging items in the study was 'God created the world'. Already at the beginning of confirmation time, average approval in the countries was as low as $38 \%$ among the confirmands, with much lower approval rates in some of the countries (for example, in Sweden: 22\%). These rates did not change much during confirmation time, which implies that possible doubts in creation faith were not addressed successfully, if at all. Two years after confirmation, the approval of faith in creation had decreased even more (international average: 34\%, Schweitzer et al. 2017:266). This result concerning faith in God the creator is an example for how the study could help improve confirmation work.
It makes the ministers and workers aware of problems in the understanding of the Christian contents taught to the young people.

- Relevance of the contents: Several questions in the questionnaires were related to the confirmands' interest in certain topics. One key question directly addressed the issue of perceived relevance: 'What I learnt in confirmation training has little to do with my everyday life'. In all, 45\% agreed with this statement (European average). This indicates that confirmation work has only been partly successful in showing young people how the Christian tradition is related to their own faith and life. This observation is further supported by the results concerning the church and the adolescents' relationship to the church.

- Relationship to the church: First of all, and as a surprise to many observers, the adolescents have a very positive view of the church. At the end of their confirmation time an average of $73 \%$ of them agree to the item 'The church does a lot of good things for the people'. At the same time, however, it is only $40 \%$ who say that it is 'Important' to them 'to belong to the church'. In other words, even after one or two years of confirmation time, most of the adolescents perceive the church as a beneficial institution, which, just like a trustworthy bank or hospital, operates quite independently especially from its younger members. The question following from this must therefore be how young people can be given a better sense of how a church depends on the participation and influence especially of its adolescent members - an impression they will only be able to gain if they are given the chance to really have a say in church.

Concerning the relationship to the church, another item must be taken into consideration as well - an item which we adopted from a general survey on youth in Germany. 'The church does not have answers to the questions that are important for $\mathrm{me}^{\prime}$. In this case, it was $32 \%$ who agreed at the end of confirmation time. It must be added that this number increased from the beginning to the end of confirmation time, which shows that there is not only the issue of relevance but also the challenge of finding convincing answers to what matters to the young people.

- Worship services: One of the intentions of confirmation work stated in respective guidelines is related to introducing young people to the meaning of worship services as a central part of Christian life. In many congregations the confirmands are obliged to attend a certain number of services, which testifies to the importance of this aim. At the same time it is a given in most European countries that young people attend worship services only rarely, be it before or after confirmation. It is no surprise then that many adolescents view worship services rather sceptically. At the beginning of confirmation time, 50\% agree to the statement 'Church services are usually boring'. What should not be expected, however, is that the respective percentage is up to $54 \%$ at the end of confirmation time. This result indicates another important challenge for the future. How can the confirmands be given a chance for more attractive encounters with worship services? In this respect, the results from the 
studies indicate a clear direction. Young people want to experience forms of worship that they consider adequate for adolescents, and they would like to contribute their own ideas to the services in general.

- Volunteerism: One of the results that surprised and also encouraged me the most refers to the role of volunteers in confirmation work. In my own country, we calculated that about 60000 volunteers are active in confirmation work every year, and many of them are only a few years older than the confirmands. This means that there is about one volunteer for three to four confirmands in Germany. In Finland, the ratio is even more impressive. An important implication of this result refers to the question of what comes after confirmation. Traditionally, many ministers complain that the adolescents will stay away from church after their confirmation. Seeing so many of them continue as volunteers after confirmation means that the invitation to become a volunteer in this field after confirmation is of key importance.

- For this reason, the study also looked into the question what factors are responsible for the decision to become a volunteer. The answers are both discouraging and encouraging for confirmation work. What is discouraging is the fact that many factors relate back to experiences in childhood, most of all to the religious upbringing in the family and to having parents who were or are active as volunteers as well. Becoming a volunteer appears to be somewhat hereditary, as it were. Yet confirmation work itself also plays a role as a factor for becoming a volunteer, which is encouraging for this programme offered to adolescents. Good experiences with confirmation work are of influence in general but there also are specific influences, for example, of having had a chance to try out voluntary work during confirmation time. This is another example for how empirical research can uncover possibilities to be used in shaping educational programmes more effectively.

These are only some of the many results to be found in the different studies. Because the main interest in the present context is not confirmation work as such but research on nonformal religious education, I will not continue by reporting results on confirmation work but by reflecting these results in terms of such research in religious education and practical theology in general.

\section{Implications for the understanding of research on non-formal religious education}

This article started out with a critical review of research in religious education and practical theology. The lack of empirical studies on non-formal religious education is a serious weakness of this field. Against this background I will offer a number of observations and considerations concerning the question of what can be learned from the example of international research on confirmation work described in the present article.

\section{Feasibility of research}

It is certainly easier to do research in schools than in the nonformal sector. This view holds true in spite of the positive experiences with the research projects on confirmation work. Even if confirmation work can be counted among the more formalised varieties of non-formal religious education because it has a comparatively firm institutional basis, this difficulty has to be admitted. Yet by only doing research in schools, one will not be able to gain insights into the reality of forms of religious education outside the school. This is why it is important to also state that the project on confirmation work can indeed be considered as evidence of the feasibility of meaningful research in this field. Obviously, it is possible to carry out research in the non-formal sector without bypassing the rules of empirical research.

Based on the experiences from this project, it is important to develop research designs that fit the specific non-formal situation in question. Researching confirmation work allows for making use of the groups of confirmands meeting on a regular basis. This makes it comparatively easy to actually reach at least most of them even with repeated questionnaires. The situation is quite different 2 years after confirmation when the groups have ceased to exist. In our case, we asked the confirmands for letting us have their digital contact data (in addition to their postal addresses if they were willing). This made it possible to send them questionnaires onto their smartphones, which proved to be an efficient way of reaching them. Currently, in another follow-up project still in process, we are involved with a study with 18- to 26-year olds looking back at their confirmation time. In this case, there had been no prior contact with the respondents on which we could have relied. Consequently, we had to involve a general research institute, which works with various samples of possible respondents. Researching non-formal religious education obviously requires flexibility, in line with different situations, but this does not question its feasibility, at least not in a general sense.

\section{Making non-formal religious education visible}

Without wanting to praise our own work, it is probably justified to claim that the research project on confirmation work - together with its publications, conferences, individual lectures and shared presentations in many places and different countries - has strongly contributed to making people aware of the actual scope and meaning of confirmation work today. This is true for the churches that have come to realise that this field of work deserves continuous attention in church leadership. It is also true, at least to some degree, for a wider public in the academy and in society at large. Moreover, we made a number of efforts to demonstrate that confirmation work should also be viewed and appreciated as education for civil society, for example, in terms of supporting social values and commitment to the common weal or, to make it more concrete, in terms of motivating young people to become volunteers. In sum, it seems fair to say that confirmation work has clearly benefitted from its increased 
visibility, in terms of motivating people for this field of work and of gaining new recognition for its achievements.

\section{A critical mirror for the practice of confirmation work}

Research always implies some kind of evaluation, at least to some degree. Our study intentionally avoided the danger of creating an international rating system for confirmation work like, for example, with the well-known PISA studies. Yet we could not avoid - and we did also not want to avoid providing a critical mirror for the actual practice in this field. In my understanding, such a mirror provided by research results is much needed, in any kind of work. It necessarily shows both strengths and weaknesses. In fact, experienced practitioners have always known that they have to be aware of both, their own successes as well as their short-comings. Yet research can carry such self-reflection as a decisive step further by offering a more systematic and thorough analysis based on empirical methods and also on the cooperation of an international team of experts.

\section{Research as a starting point for improvements}

The critical function of research would, however, not be helpful if there would not also be its constructive function of identifying perspectives for future improvements. As has hopefully become clear in the preceding section on the main results of the study, there are in fact many such perspectives addressed in the results, be it concerning worship services or concerning the presentation of the Christian faith in teaching. Moreover, the issue of long-term effects of confirmation work deserves increased attention in the future, among others, by becoming more systematic with approaches to working with young volunteers. However, it should not be taken for granted that perspectives for future improvements identified in research will be actually taken up in the field. The relationship between theory or research and practice is always complex and difficult. It is therefore a task of its own to bring together research and practice, not in the sense of a unilateral deductive relationship but as a dialogue between researchers and practitioners. In the case of the studies on confirmation work, many efforts have already been undertaken in this respect, with conferences and presentations, etc. Yet even more efforts are needed - joint efforts of researchers, church leaders and of those in charge of the initial and continuing training of ministers and other workers and also of the practitioners themselves.

\section{Empirical research and theological interpretation}

Given that the relationship between empirical research and theological interpretation has been a key question in practical theology at many times, for example, with the discussions on so-called empirical theology (cf. van der Ven 1990), it is no surprise that this question must also be posed concerning research on non-formal religious education. My main emphasis in this article has been on empirical research. Yet it has also become clear that this research started with theological considerations concerning both the Protestant tradition in education as well as theological concerns in respect to informal and formal religious education in the family, the media and in schools. Moreover, theological interests have been included in the research instruments, for example, with the emphasis on worship services, presenting the Christian faith and the inclusion of volunteers. Finally, empirical results do not just speak by themselves. Theological interpretation is needed for making use of them for advancing the field, for discerning what should be considered true potentials and what might look promising but is not adequate for a programme offered by the church. In other words, just like in other cases in this context, it is an interplay between theoretical or theological and empirical approaches that is needed in researching and advancing the practice of nonformal religious education. That this interplay can actually be realised, in dialogue between theory and practice, should therefore be a constant aim in this kind of research. Empirical research does not lead away from theology but can bring it into play in new ways.

\section{Acknowledgements Competing interests}

The author declares that he has no financial or personal relationships which may have inappropriately influenced him in writing this article.

\section{References}

Bäumler, C. \& Luther, H. (eds.), 1982, Konfirmandenunterricht und Konfirmation. Texte zu einer Praxistheorie im 20. Jahrhundert, Kaiser, München.

Bundesministerium für Bildung und Forschung (ed.), 2008, Stand der Anerkennung non-formalen und informellen Lernens in Deutschland im Rahmen der OECD Aktivität 'Recognition of non-formal and informal Learning', Bundesministerium Aktivität 'Recognition of non-formal
für Bildung und Forschung, Bonn.

Douglass, K.M., 2015, 'The confirmation project in the United States. A study of confirmation and equivalent practices in the American context', in F. Schweitzer, K. Niemelä, T. Schlag \& H. Simojoki (eds.), Youth, religion and confirmation work in Europe: The second study, pp. 318-327, Gütersloher Verlagshaus, Gütersloh.

Francis, L.J., Kay, W.K. \& Campbell, W.S. (eds.), 1996, Research in religious education, Gracewing/Smyth \& Helwys, Leominster.

Hull, J.M., 1984, Studies in religion and education, Falmer, London.

Hyde, K.E., 1990, Religion in childhood and adolescence: $A$ comprehensive review of the research, Religious Education Press, Birmingham.

Jackson, R. (ed.), 2012, Religion, education, dialogue and conflict: Perspectives on religious education research, Routledge, London.

Jetter, W., 1988, 'Katechismuspredigt', in G. Krause \& G. Müller (eds.), Theologische Realenzyklopädie, vol. 17, pp. 744-786, De Gruyter, Berlin.

Larsson, R. \& Gustavsson, C. (eds.), 2004, Towards a European Perspective on Religious Education: The RE Research Conference, March 11-14, University of Lund, Artos \& Norma, Skellefteå.

Luther, M., 1982a, 'An den christlichen Adel deutscher Nation: Von des christlichen Standes Besserung', in G. Bornkamm \& G. Ebeling (eds.), Martin Luther Ausgewählte Schriften, vol. 1, pp. 150-237, Insel, Frankfurt.

Luther, M., 1982b, 'Eine Predigt Martin Luthers, dass man Kinder zur Schule halten solle', in G. Bornkamm \& G. Ebeling (eds.), Martin Luther, Ausgewählte Schriften, vol. 5, pp. 90-139, Insel, Frankfurt.

Niemelä, K., 2008, Does confirmation training really matter? A longitudinal study on the quality and effectiveness of confirmation training in Finland, Church Research Institute, Tampere.

Paul, E., 1995, Geschichte der christlichen Erziehung. Part 2: Barock und Aufklärung, Herder, Freiburg im Breisgau.

Schreiner, P. \& Schweitzer, F. (eds.), 2014, Religiöse Bildung erforschen. Empirische Befunde und Perspektiven, Waxmann, Münster.

Schweitzer, F., 2006, Religionspädagogik, Gütersloher Verlagshaus, Gütersloh.

Schweitzer, F., 2016, Das Bildungserbe der Reformation. Bleibender Gehalt, Herausforderungen, Zukunftsperspektiven, Gütersloher Verlagshaus, Gütersloh. 
Schweitzer, F. \& Boschki, R. (eds.), 2017, Researching religious education: Structures and outcomes, Waxmann, Münster.

Schweitzer, F. \& Elsenbast, V. (eds.), 2009, Konfirmandenarbeit erforschen. Ziele Erfahrungen - Perspektiven, Gütersloher Verlagshaus, Gütersloh.

Schweitzer, F., Ilg, W. \& Simojoki, H. (eds.), 2010, Confirmation work in Europe: Empirical results, experiences and challenges. A comparative study in seven countries, Gütersloher Verlagshaus, Gütersloh.

Schweitzer, F., Niemelä, K., Schlag, T. \& Simojoki, H. (eds.), 2015, Youth, religion and confirmation work in Europe: The second study, Gütersloher Verlagshaus, Gütersloh.
Schweitzer, F., Schlag, T., Simojoki, H., Tervo-Niemelä, K. \& Ilg, W. (eds.), 2017, Confirmation, faith, and volunteerism: A longitudinal study on Protestant adolescents in the transition towards adulthood. European perspectives, Gütersloher Verlagshaus, Gütersloh.

Strommen, M.P. (ed.), 1971, Research on religious development: A comprehensive handbook, Hawthorn, New York.

Van der Ven, J.A., 1990, Entwurf einer empirischen Theologie, Kok/Dt. Studien-Verl., Kampen.

Vischer, L., 1958, Die Geschichte der Konfirmation. Ein Beitrag zur Diskussion über das Konfirmationsproblem, Evang. Verl., Zollikon. 